Article

\title{
From Missionaries of Socialism to Spies of Imperialism: The Shifting Position of Soviet Women in Communist Albania
}

\author{
Artan R. Hoxha
}

Citation: Hoxha, A.R. From Missionaries of Socialism to Spies of Imperialism: The Shifting Position of Soviet Women in Communist Albania. Histories 2021, 1, 256-266. https:// doi.org/10.3390/histories1040021

Academic Editor: Jon Mathieu

Received: 20 August 2021

Accepted: 18 October 2021

Published: 27 October 2021

Publisher's Note: MDPI stays neutral with regard to jurisdictional claims in published maps and institutional affiliations.

Copyright: (C) 2021 by the author. Licensee MDPI, Basel, Switzerland. This article is an open access article distributed under the terms and conditions of the Creative Commons Attribution (CC BY) license (https:// creativecommons.org/licenses/by/ $4.0 /)$.
Institute of History, Academy of Albanological Studies, Center of World History, University of Pittsburgh, Pittsburgh, PA 15260, USA; arh99@pitt.edu

\begin{abstract}
After the establishment of the communist regime in Albania, many Albanian students, mainly males, went to study in the Mecca of Revolution-the Union of Soviet Socialist Republic (USSR). Many of them fell in love there and married Soviet girls who returned with them to the tiny Balkan country to build socialism with their Albanian husbands. These women were considered as missionaries who were helping Albania to build a communist future. In 1960, however, their position changed when the Albanian leadership refused de-Stalinization and denounced the Soviet Union as an imperialist power. After Enver Hoxha's split with Khrushchev, many Soviet women left Albania, but others decided to remain with their husbands in that country. Albanian authorities, considering Soviet women spies of the KGB (The Soviet Committee of State Security), persecuted many of them.
\end{abstract}

Keywords: Soviet women; Albania; communism; hybridity; citizenship; persecution; Enver Hoxha

\section{1961: Tirana's Break with Moscow, and the Soviet Women Living in Albania Married to Albanians}

At 6 p.m. on 5 December 1961, the Politburo of the Albanian Labor Party's Central Committee (ALP's CC) gathered in an urgent meeting. That morning, on behalf of the government of the Soviet Union, Yuri Andropov announced the cessation of the USSR's diplomatic relations with the People's Democratic Republic of Albania. It was a dramatic moment. The Soviet bear had finally had enough the communist leadership of the tiny Balkan country, the southernmost outpost of the Soviet bloc and its only Mediterranean outlet. Albania's communist boss, Enver Hoxha, had fervently opposed both de-Stalinization and the intention of the Soviet leadership under Khrushchev to mend the fences with Yugoslavia [1]. Albeit small, the Albanians had made a huge noise that upset the Kremlin.

The Soviet leadership found it difficult to discipline the Albanian communist strongman and his supporters. Khrushchev, at one point, identified the root of their attitude, differentiating between the northern and southern countries of the Soviet bloc: Albanians were southerners, people with hot blood who did not know how to remain calm (this is what the anthropologist Michael Herzfeld called Mediterraneanism, a form of Orientalism that replaces the east-west with the north-south divide [2]). The bear finally reacted from its den in the cold and snowy north. In concert with the other Eastern European countries, Moscow broke off its diplomatic relations with Tirana, thus putting an end to the muchneeded financial, technical, and technological assistance it had hitherto given to its tiny Balkan ally.

Actually, neither Albanians nor Soviets thought of the break as terminal; both parties involved considered that the whole matter would be a temporary situation. As it turned out, it was not. The Albanians were hoping that, in the near future, either Khrushchev or his successors would reverse the course of de-Stalinization. On its side, the Soviets knew how vulnerable Albania was. Economically, the country could not survive without foreign help, and from the standpoint of security it was caught between two enemies, Greece and Yugoslavia. The Kremlin's solution was to terminate economic assistance, assuming that the Albanians would return as docile lambs to the Soviet sheepfold. Hoxha, however, was 
not a lamb. His growing disagreements with Khrushchev occurred concomitantly with the latter's alienation from the Chinese leadership. With this fortuitous situation working to his benefit, Hoxha exploited the friction between Peking and Moscow: he gained Mao's support and China's economic assistance, which enabled the Albanian communist regime to continue to survive for more than a decade and a half [3]. The quarrel between Hoxha and Khrushchev was one of those moments demonstrating the thin façade of rhetoric that overlaid the alleged unity of the Soviet bloc. Most importantly, Albania's split with the Soviet Union exposed the profound distrust this communist strongman had toward his ally's goals. His deep and pervasive sense of insecurity left its mark on the history of Albania until the end of the ALP's rule [4]. The internationalist brotherhood of Albania reached an end in 1961.

The break with the Soviet Union and the socialist bloc in Europe proved to be a pivotal moment in the history of communist Albania. After 1961, although theoretically opened to the global revolutionary movement occurring at that time, Enver Hoxha sealed off the country he controlled from the wider global socialist world led by Moscow. As one scholar rightly argued, from the relative openness to the global socialism which generally characterized the 1950s, a warfare and siege mentality dominated the relations of Tirana's regime with the rest of the world [5]. From 1948 to 1961, the Soviet Union and its East European allies had given immense support to the poor Albania to help it build socialism. During the almost thirteen years of this romance, many specialists from the countries of the Soviet bloc came to Albania, where they widely interacted with the local population as windows to a broader world [6-8]. However, this transnational tapestry of socialist brotherhood wholly changed after the "divorce" of 1961. Telling in this regard is the attitude of Tirana's authorities toward the Chinese specialists dispatched by Peking to Albania to assist the latter in furthering its communist leadership's project of industrialization. In contrast to the declaration of the ALP's top echelons as to the fraternity between the two countries, the Chinese technicians lived in separate quarters and had almost no interaction with the locals [9].

The self-imposed seclusion of the Albanian communist regime toward the world, the ossification of the mentality of war and, as a consequence, the growing suspicion of everything considered foreign impacted the foreigners who had settled in Albania. This same attitude was also held towards many Soviet women who married Albanian men during the 1950s. The romance between communist Albania and the Soviet Union of this decade and the two-directional flow of people between the two countries resulted in love affairs at the grass-roots level. Many of these romantic relationships-mainly between Albanian men and Soviet women-ended up in marriage. As described in this article, the arrival of the Soviet women to this most distant outpost of the socialist bloc was an outcome of the transnational fabric woven in the loom of socialist globalization. The transitioning of Albania toward a more isolationist course, and the growing weight of nationalism and xenophobia evident in Hoxha's communist regime, impacted the position of the majority of the Soviet women in Albania. The Hoxha-Khrushchev dispute and the political and ideological ramifications that accrued from it entered the home of many Albanian-Soviet couples.

On the evening of 5 December 1961, Hoxha gave instructions on what were meant to be temporary measures to counter the extraordinary situation of women from an enemy country living in Albania. Among other issues he raised was that of the Soviet women married with "our people". The majority of them, he said, would leave. "Let them leave", the Albanian Labor Party's boss instructed. He made a clear distinction between "our boys" and "their wives". The Albanian men belonged to the regime, to the party, to Albania, however, this was not the case with their Soviet wives. They belonged neither to Albania nor to the ALP. An irreconcilable line divided $u s$ from them. The regime treated individuals according to their citizenship, nationality, and ethnic identity. According to the communist boss, Soviet women married to Albanians were Kremlin's extensions in Albania, declaring that he considered these women to be nothing but Soviet spies. He 
ordered his subordinates to call on their husbands and tell them that it would be better if their wives left the country because of their hostile activities. If the wives did not accept, Hoxha continued, they would be put under surveillance. Alternatively, the Soviet women could obtain Albanian citizenship, and when the two countries mended their fences, the issue could be revisited [10].

The historian Elidor Mëhilli explored, in several of his works, how Albania was part of the larger picture of global socialism during the second half of the 20th century. He examined both the flow of people and the movement of ideas in and out of Albania from 1945 through 1990 and how these impacted the country during the communist period [11]. However, research still needs to be done on those people who went to Albania as part of the transnational connections forged during the 1940s-1950s, and who stayed there for the remaining decades of the communist era. This is especially true for citizens of countries considered enemies by the ALP's leadership. Communist regimes understood the world through big-brush categories that simplified the social landscape. Generally speaking, for these regimes' citizenship, as well as identity in the form of class, region, culture, or ethnicity, defined the political allegiance of individuals [12]. Shannon Woodcock argued that the Albanian communist regime, too, considered these identities as primary criteria for defining its enemies and subjecting those enemies to prophylactic interventions [13]. The goal of this article is to expand on her research. Exploring the status of foreign citizens-in this case, of Soviet women in communist Albania-helps in understanding how politics and gender intersected in the social construction of the "enemy" in one of the most notorious dictatorships of Europe during the second half of the 20th century [14].

\section{Soviet Women Going to Albania as Missionaries}

The story of the Soviet women persecuted and jailed in communist Albania started in Moscow before they even arrived in the Mediterranean corner of the Socialist bloc. After WWII, with the permission of Stalin, Albania initially fell under Yugoslav patronage. Tito's ambitions and lack of will to pursue Stalin's agenda caused the expulsion of Yugoslavia from the Soviet bloc. Hoxha used this split to his advantage and established direct links with Moscow. From that moment, Albania integrated without any mediation into the expanding socialist world. Stalin, using the Yugoslav efforts to transform Albania into the seventh republic of the federation as a justification for attacking Belgrade's leadership, gave full support to the ALP to build socialism on the shores of the Adriatic [15].

Economically, Albania was poor: the communists had to build practically everything from scratch. Besides the lack of infrastructure and economic resources, Albania did not possess the essential human capital for rapid modernization. Almost 85\% of the population was illiterate, and few had university education-only a fistful educated in Italy, Germany, and France during the interwar period. Stalin agreed to help the Albanians and train in the USSR those managers, engineers, and technicians who were going to modernize Albania [16]. In the meantime, thousands of Soviet specialists landed in Albania and provided their expertise in every project that took place in the country during the 1950s. In addition to their skills, they also brought new lifestyles. Enjoying the balmy Mediterranean climate, these Soviets and their families made a name for themselves with the weekly parties and excursions to the Adriatic and Ionian seas organized by their Albanian counterparts.

The movement of people between Albania and other Soviet bloc countries was a two-way street indeed. While thousands of East European and Soviet specialists arrived in Albania, other thousands of young Albanians left their native land to study at institutions of their East European sisters, especially in the Soviet Union, where Moscow and Leningrad were the primary destinations. The majority of the Albanian students were males from rural areas who had either participated in the partisan movement or came from families tied to the new regime. Their transition to the Mecca of communism was both exciting and traumatic, indeliblely transforming their lives. Their horizons were expanded not only through university education and student life, but also through experiences accumulated in the principal Soviet urban and cultural hubs. These students were initiated into a 
fascinating world of various ethnicities, races, and languages, of immense urban landscapes, of the intellectual and material culture they generated, and of the models of life that Moscow and Leningrad radiated. The Albanian students became not only repositories of technical skills, but also ambassadors who transported these new lifestyles back to Albania.

The young people from Albania often earned a good reputation where they studied and lived. Though Albania was poor, the prolonged influence of Italian influence during the 1930s and the early 1940s had left behind much of the Italian sartorial style, especially among the males. Before leaving for the USSR, these young students used their savings to buy tailor-made Italian-style suits. These hit the mark at the foreign universities, and especially in the large urban hubs of the Soviet Union, where the growing consumer culture which started in the 1930s reached its apex in the 1950s. From the revolutionary asceticism of the 1920s, Soviet society shifted gradually toward a more consumerist outlook and sophisticated tastes, especially visible in fashionable dress. Consumption became a marker of civility (kul'turnost'), which had a class dimension and with which the intelligentsia became the representatives of this new standard of living [17,18]. By the mid-1950s in cities like Moscow, being chic became almost mandatory among the youth, especially for the young women. This significant cultural transformation occurred in conjunction with the growing visibility of women in Soviet society after WWII as they moved out of the kitchen and started climbing up social and professional ladders. During the 1950s, women became more active and were more highly visible in public life and in the roles they performed [19,20].

The youth, especially those at universities, nurtured high aspirations for social and professional achievements and, in anticipation, embraced the consumerist ethos with great zeal. In such an environment, the young men from the poor corner of Southeast Europe distinguished themselves with their Italian style of dress and well-combed hair slicked down with brilliantine. Many of them fell in love with Soviet women and married them. In the internationalist ambiance of Moscow, Leningrad, and other large urban centers of the European part of the Soviet Union, nationality and ethnicity were not barriers for starting enduring relationships. Moreover, the victory over the German army was still fresh, reinforced even, and gave new vigor to the missionary spirit of communism. The "communism in one country" of the 1930s belonged to the past. Now, socialism had gone international, and Soviet youth felt the call to be part of history. They shared optimism about the future and confidence about the ultimate triumph of communism. This vibrant social environment, permeated by a sense of internationalist brotherhood along with a missionary spirit, helped the Albanian students forge relationships with Soviet students, marked by love that blossomed at the universities. Many young Soviet women left their own country and the broader opportunities it offered to follow their husbands to their native Albania.

Moving to Albania, though, was filled with legal obstacles for these young Soviet brides. In February 1947, the Soviet Presidium had passed a law that prohibited the marriage of Soviet citizens with foreigners. It was the beginning of the Cold War and Stalin was afraid that foreign spies could use Soviet citizens to infiltrate the country as spouses. That same year, the communist authorities in Tirana passed a similar decree that restricted the possibilities of Albanian citizens marrying foreigners. The Albanians were not merely mimicking the Soviets-the law was actually an expression of a genuine political will of the ALP's leadership to minimize any independent relations between Albanian and citizens of other countries, including those from the Soviet bloc. According to this law, marriages between Albanians and foreign citizens were legally valid only after Albanian state authorities granted permission to such unions.

Regardless of what was on paper, the Albanian regime openly expressed unwillingness to grant permission for such unions. Vice Prime Minister and Minister of Interior Mehmet Shehu voiced concerns as to security, especially about the possibility of potential infiltration from Poland, Hungary, and Czechoslovakia [21]. The Albanian communist leadership harbored deep suspicions about the most Western-oriented countries of the bloc. Following 
this line of thought, the Ministry of Foreign Affairs considered as undesirable the arrival of foreign spouses to Albania. The Albanian government declared that it would consider non grata all foreign citizens who married Albanian citizens, and did not permit them to return to their own countries. In this spirit, the Ministry of Education and the local ALP's committees instructed students to not get engaged to foreign women. They were to go abroad, become educated, and return to Albania ready to serve their country. However, not long after these students started their studies in the countries of the socialist bloc, requests for marrying women of foreign nationalities increased exponentially. The answer of the Albanian regime was drastic and radical: in 1952 it passed a law that altogether forbade marriages between Albanian nationals and foreign citizens [22].

Laws and decisions notwithstanding, the requests of Albanian students who asked for permission to marry foreign women increased. The 1954 decision of the Soviet government and the other East European countries to abolish laws that forbade their citizens from marrying foreigners put the Albanian authorities in an uncomfortable position. In response to the increasingly relaxed atmosphere that followed Stalin's death, the Albanian Ministry of Justice sent a memo to the ALP's Politburo requesting the abrogation of the law that forbade marriages of the Albanian nationals with citizens from countries of the socialist bloc. The Minister of Justice, Bilbil Klosi, took a utilitarian approach and highlighted the advantages of these unions. He stated that that the majority of those who applied to marry foreign citizens were students, and their spouses were students as well. According to Klosi, these foreign spouses were precious human material that could play an important role in the construction of socialism in Albania. Regardless of his arguments, the ALP leadership did not share the enthusiasm of the Minister of Justice and decided to permit only marriages between Albanians and Soviet women while preserving the restrictions on citizens from other countries of the bloc [21].

Formally, at least, Tirana's leadership was forced to comply with the legal norms that the Soviet Union and the other countries of the bloc implemented after the death of Stalin. In 1954, the Albanian communist regime finally granted foreign citizens the right to preserve their native citizenship [23]. Immediately after the passing of the law on 7 February 1955, many of the requests materialized and, now permitted to be married, Albanian-Soviet couples headed to Albania from Moscow, Leningrad, Kyiv, and other Soviet urban areas.

Although now more open about marriage of Albanians to Soviet citizens, the state preserved the right to approve or reject marriages of its citizens with "outsiders" [24]. Despite passing the law, Tirana's authorities viewed with concern the growing number of foreign women that came to Albania with their husbands and tried to prevent this phenomenon as much as possible. Many students challenged the regime and married without waiting for approval—some did not even ask permission. The Soviet authorities, too, pressured many of the young women not to leave their own country. They treated these women with suspicion and considered them almost as traitors for leaving. When they did come to Albania, the Soviet Embassy excluded them from the activities it organized. State authorities, however, were not the only ones putting obstacles in their paths. In many cases, the families of both grooms and brides also opposed these relationships

In Albania, many resented these unions and considered them an offense towards Albanian women. "Why? Are those Russians better than our girls?" was a question people asked upon seeing these young men returning with spouses from the Soviet Union [24]. In some cases, men who had been married before leaving for university divorced their wives during their time away, which caused adverse reactions not only among the families of the students but also in the ALP's leadership, which held a stern and a strongly supportive attitude towards family [25-27]. Many Albanian mothers were not at all pleased when their sons brought home foreigners. Still attached to the notions of large patriarchal families, they disliked having in their homes Russian women whose language and customs they did not understand. On the other hand, the families of the Soviet women opposed the choices of their daughters who abandoned the opportunities of Moscow and other large Soviet 
cities and permanently moved far away. Despite such pressures, many of these young women did not change their minds and determinedly joined their husbands returning to Albania.

Upon arrival to their new country, the young Soviet women, wearing modern dresses and sunglasses, were shocked to discover that their well-dressed husbands did not represent the typical standard of living of their own home country. Kul'turnost', argues Vadim Volkov, was part of the Stalinist internal civilizing mission [28]. It embodied attitudes that the power hierarchies of the Soviet well-educated class of the urban centers had toward poor, backward, non-modern cultures along the periphery of the Soviet bloc. These women, many of whom held university degrees, represented the Zeitgeist of post-war USSR. The shock they experienced upon arriving in Albania-which for them represented the antithesis of Moscow and Leningrad - reflected the geographical and cultural hierarchies that dominated the well-educated Soviet urban class. The first indication that alerted these Soviet women that they had entered a different world was the small airport of Tirana. The few cars moving around the capital on irregular meandering roads, women wearing wooden slippers and large, black, loose pants (shallvare), and old men dressed in national costumes topped by the Albanian white pointed felt headgear (qeleshe) all portrayed social and physical landscapes that were far from modern. In many cases, their reactions were primarily framed by Orientalist perceptions and by the concern that their aspirations of being modern had disappeared forever. Some of them thought they had landed in an Oriental rather than in a European country [29,30]. The world they encountered in their newly adopted home tested the internationalist fervor of many of them. Not surprisingly, the cultural shock experienced by the Soviet wives upon arrival in Albania led to conflicts and divorces [24,25].

This cross-cultural experience, however, offered another side, brighter and more optimistic. Albania was a country that had to build almost everything. As such, it provided numerous professional opportunities for many of these women to use their skills, education, and knowledge to help modernize the country. In the mid-1950s, the Albanian-Soviet friendship was still strong, and Albania was part of a worldwide camp with the Soviet Union at its center. With Russian as the mandatory language in the schools, and with the presence of thousands of Soviet specialists and Soviet-educated Albanians, many Soviet wives married to Albanians thought of themselves as just living in a remote region (oblast) of the USSR. Many of them, thanks to their education and their husbands, were employed in excellent positions within the expanding state apparatus and scientific sector. Thus, many of these women did not lose their status but, on the contrary, became members of the privileged, emerging Albanian intelligentsia, of the technocratic or artistic elite. As true missionaries, they moved to the frontline of building socialism by the shores of the Mediterranean as they helped modernize the agrarian society in which they found themselves.

Many of the Soviet women who had married in their own country but were now living in Albania thrived and provided outstanding contributions to the modernizing project of the communist regime. As the Minister of Justice foretold back in 1954, their skills, knowledge, and expertise were precious in a country plagued by the scarcity of experts. Out of the sixty-nine Soviet women who remained in Albania throughout the communist period, four were doctors, twenty-three were professors in the newly found University of Tirana (1957), and fifteen were engineers, in addition to one artist, one movie director, two lawyers, one agronomist, and three economists. The remainder were housewives or had modest occupations [31]. To name a few prominent examples, Luisa Melnikova provided outstanding help in the creation of the laboratory of criminology and the elaboration of the standard texts of jurisprudence; Volya Vasilyevna built the first geological laboratory in the country; Maya Polakova established, with her husband (Skënder Luarasi), the Department of English in the University of Tirana; Nina Odiankova was one of the most prominent sopranos in the country; there were also one of the first oculist doctors in the country, Taisja Uzlova, and the engineer Taisja Batkhina who worked in the textile industry. 


\section{The End of the Honeymoon}

The first signs of the future storm in Soviet-Albanian relations surfaced in 1956 when Khrushchev started his de-Stalinization campaign, which resulted in huge and unanticipated repercussions throughout the socialist bloc. Enver Hoxha resisted the process. Although he did not face anything similar to what happened to the Stalinist guard in Poland or Hungary, his power was criticized and challenged in Tirana by a group who had been mainly educated in the Soviet Union and other East European countries. They wanted a more merit- based hierarchy within the party, and termination of the privileges of the ALP's leadership. Hoxha reacted harshly and crushed his opponents with an iron fist [32]. More importantly, the Albanian strongman pin-pointed those who had been educated in the USSR as a group that threatened his power. In his analysis of Khrushchev, Hoxha considered him to be the representative of the Soviet intelligentsia. The Albanian strongmen turned upside down Trotsky's, Timasheff's, and Djilas' theories of the roots of Stalinism [33-36]. According to him, the Soviet intelligentsia was at the root of revisionism and the social basis that supported Khrushchev's anti-Stalinist crusade. While the Soviet concept of intelligentsia was a broad social category which also included the state and party bureaucracy, Hoxha used it in a quite narrow sense, defining it as the educated technocratic and cultural elite, i.e., those Albanians who had been educated in the Soviet Union and Eastern Europe.

The ALP's leadership was already well aware of both the cultural shock that the Albanians' Soviet wives experienced upon their arrival in the country, and their high demands. Divorces between some of them and their Albanian husbands had already taken place, the majority caused by conflicts with in-laws, or because their husbands' low salaries could not meet their lifestyle expectations [25]. Their consumer-oriented values became a problem and reinforced the prejudices the ALP leadership had about Albanian-Soviet couples, especially those from the ranks of the intelligentsia. The Central Committee resented the choices of the Albanian men who married foreign women. Top members of the ALP's Politburo complained that the state had sent these young men to the USSR to learn new skills and accumulate knowledge for use in modernizing Albania, and what did they do? Consort with Soviet women and marry them [24]! In other words, in the Fatherland of Communism, many Albanian young men had been taught to think about themselves and not their country. In the large Soviet metropolises, they were exposed to and internalized individualistic principles rather than collectivist values.

Meaningful is the case of Selman Borshi. In Moscow, he studied forest engineering and afterwards returned to Albania to work in the newly opened University of Tirana, but while in the USSR he met and married Suzana Zaytceva. Not long after they had settled in his native country, they started to request permission to return to Moscow on the grounds that it was their free choice to choose the country where they wanted to live. Besides, Zaytceva insisted that she had no career opportunities in Albania, while back in Moscow her mother was alone and needed her assistance. Her husband fully supported her. Hysni Kapo, the third most powerful man of the regime, ordered his subordinates to call on Selman Borshi and give him "a good beating" so he could understand his "mistakes". Hoxha personally gave the order to not allow him to leave the country, and another member of the ALP's top brass proposed to transfer him to a remote area where hard work and tough life conditions would temper and harden him [37], evidently believing that a rough life and work in the countryside would be effective neutralizers against the influence Borshi's Soviet wife exerted on him.

Hoxha and the ALP's leadership saw in the lifestyle the young men brought back with them from abroad - the materialist and consumerist culture of the 1950s of the large Soviet urban centers-symptoms of the ideological "decay" that had pervaded the USSR for the past decade. In their eyes, the decrease of the revolutionary fervor and the embourgeoisement of the intelligentsia in the Soviet Union were manifestations of the ideological corruption that had brought Khrushchev and his "gang" to power and corroded the legacy of Stalin. As a consequence, Hoxha and his closest associates became increasingly sus- 
picious of the Soviet-educated Albanian intelligentsia, and especially of those who had married Soviet women who had the same educational background as their husbands. In this context, in December of 1961 Hoxha's Albania broke off its relations with the USSR and forged a new alliance with Mao's China. This is when the Albanian communist leader began to view Soviet spouses as Kremlin's spies.

From the moment of the Albanian-Soviet split, Hoxha's regime considered as spies not only the Hungarian, Czech, and Polish wives married to Albanians, but also the Soviet wives of Albanian intelligentsia and army officers. In December of 1961, the Soviet Embassy called in all the Soviet women married to Albanians and told them bluntly that they had to leave their husbands, otherwise the Soviet state could offer them no protection. Of the 130 Soviet women then married to Albanians, almost half (sixty-one of them) got divorced and left the country [31].

The Albanian army officers, especially, faced huge pressure from the state. They had to choose between their work and their wives, and all who did not get divorced lost their positions in the military and were forced to seek jobs in the civil sector. The Albanian authorities put under surveillance at least 19 Soviet women and also some of their husbands who the State Security Police (Sigurimi) considered disloyal elements. In addition, the Ministry of the Interior also kept track of those men whose wives had left. Meanwhile, in 1962-1963, several Albanian army officers illegally crossed the state border, escaping to Yugoslavia in order to join their wives in the Soviet Union. They had been, according to Sigurimi, most probably recruited by the KGB. Indeed, in a report submitted to Politburo, Vice Minister of the Interior Mihallaq Ziçishti claimed that Moscow's secret services recruited several Albanians who had been studying in the USSR [38].

With Tirana's split from the Kremlin's orbit, the Soviet women married to Albanians transitioned from being part of the most privileged group of alien subjects to being the most suspected. The Albanian-Soviet couples had been an outcome of the previous political alliance between their two countries. Once the internationalist brotherhood which had made these unions possible came to an abrupt end, the life trajectories of many of these couples also took a sharp turn. The ideological and international political transitions of the Albanian communist leadership (which suffered from acute insecurity and paranoia) deeply affected the fate of many Soviet-Albanian couples who did not leave the country.

\section{Living with A Stigma: Soviet Women in Isolated Albania}

After 1961, Tirana's regime considered as a potentially dangerous social category the Albanian technocrats who had been educated in the Soviet Union and other countries of the socialist bloc. The Albanian communist state likewise also targeted many of the well-educated Soviet women, almost half of whom fell into this category ([31], sheet 17). To understand how and why part of this group of Soviet women became subject to its repressive measures requires contextualization of the three categories of nationality, gender, and class that were interwoven into the broader historical transformation that Enver Hoxha's Albania underwent in the 1960s-1970s.

The 1960s were years of uncertainty for many Albanian technocrats educated in the Soviet Union and Eastern Europe. Those married to Soviet women faced increasing pressures from their country's regime to divorce their wives. The latter reduced their communication with relatives and families in the Soviet Union. Many of them retreated to private life and became housewives, limiting their contact with the outside world and abandoning social and professional activities [39]; others continued to work, although their lives became difficult. In 1967, the Albanian communist regime started its Cultural Revolution, which Hoxha also used against the foreign-educated intelligentsia. His main goal was to dilute this group's social prestige, which Albania's communist strongman perceived as a threat $[40,41]$. The regime started the so-called circulations (qarkullime) that consisted of transferring the most prominent members of the intelligentsia to outside the country's capital and main urban centers. In this way, they were scattered across the country and cut links they had forged while working and living in the capital and other 
large urban centers. Dispersed around the country to villages or small remote towns, they would not pose any potential threat. This was just the beginning. In the coming decade, their situation became graver.

In the early 1970s, the alliance of ALP's leadership and Mao's China started to crumble. It was the moment when Mao Zedong made a swift turn-about and lost the status of pariah his country had held in the eyes of the international community. In 1972, communist China became a member of the United Nations and a permanent member of its Security Council. Once the Chinese broke their isolation and approached the United States as a strategic economic and political partner, the Albanian communist leader had to make important decisions that would affect his power and the future of the country. Peking had asked Tirana to abandon its orthodox ideological stance and economic policies, but Hoxha did not change his stance and a collision between the two partners appeared to be on the horizon. The deterioration of the relations with the Asian giant posed existential challenges for the communist leadership. The main question was what would happen after a break with China? What was to be done? Go west? Go east? For Hoxha, both scenarios meant rejecting everything he had worked for and stood for-and could very well also mean a regime change. Hoxha opted for a less feasible path. Choosing neither west nor east, Albania would move forward alone [42].

At this critical historical junction, when within the context of detente the socialist regimes in Eastern Europe relaxed their grip over their societies and increased their economic and cultural exchanges with the West, the ALP's leadership did the reverse: it tightened its control over the country and limited contacts with the outside world. Hoxha knew that his choice would create discontent among his people. He sensed their growing disaffection caused by the increasing alienation with the other countries of Europe. Hard times lay ahead.

After the USSR's invasion of Czechoslovakia, Enver Hoxha considered the Soviet Union the main threat to his Albania and feared a potential invasion from the armies of the Warsaw Treaty $[43,44]$. Driven by his paranoia, in Stalinist style Hoxha again set about to purge all those social groups he perceived as a threat to his power and which, according to him, would allegedly cooperate with foreign powers for a regime change. The technocrats, especially those educated in the Soviet Union, once more fell in his crosshairs $[45,46]$. In this historical context, well-educated Soviet women who with their husbands belonged to the technocratic elite were being targeted by the repressive apparatus of the Albanian communist regime.

Between 1973 and 1975, Sigurimi arrested 13 Soviet women, accusing them of espionage on behalf of Moscow's intelligence agencies. In Operation Foxes (Dhelprat), the Ministry of the Interior uncovered an alleged network of spies that passed to the Soviet secret services sensitive information about Albania. Part of the network also included some of their husbands who, according to the regime's accusations, had been recruited from the Soviet Committee of State Police (KGB) while they were studying in the USSR [30,47-49]. The arrested Soviet women belonged to the intelligentsia and had an active professional life; however, and more importantly, the position of the Soviet women in Albania vis-à-vis the communist regime, including the well- educated, depended in no small degree on the position of their husbands within the power structure. The regime attacked those Soviet-educated technocrats whose loyalty was uncertain and who generally stood outside of the network of the ALP's power structure. On the other hand, the state spared the Soviet women who were not engaged in public life, e.g., housewives or those who were employed, like their husbands, in humble professions. This latter category did not have a dangerous identity in a dangerous time.

ALP's leadership was concerned that Soviet-educated technocrats could give voice to the country's general discontent and articulate this by means of Marxist vocabulary their education in the USSR had supplied them. The persecuted Soviet women were victims of their husbands, of their own education, and of Hoxha's interests and paranoia. Their fragile position as related to the Tirana regime was defined by a series of nested identities 
that fatally interplayed with contingent historical factors. More than anything else, their national background overlapped with that of class. As other scholars have convincingly substantiated about the Soviet Union, class remained the basic unit of analysis in the USSR [50-52]. In the case of the Soviet women who lived in communist Albania, the regime there classified them and their husbands as members of intelligentsia educated in a country which the ALP's leadership now considered to be an enemy. Using Eric Weitz's definition, the Albanian communist regime gave to its "enemies" fixed and unchangeable proprieties [53]. Like Stalin in the 1930s, Hoxha, too, considered harsh punishments of these alleged enemies a necessary preventive measure to protect his position $[54,55]$. The persecution of a group of well-educated Soviet women in the Albania of 1970s is just another example of the same mechanism.

Funding: This research received no funding.

Institutional Review Board Statement: Not applicable.

Informed Consent Statement: Not applicable.

Data Availability Statement: Not applicable.

Conflicts of Interest: The author declares no conflict of interest.

\section{References and Notes}

1. Mëhilli, E. Defying De-Stalinization: Albania's 1956. J. Cold War Stud. 2011, 4, 4-56. [CrossRef]

2. Herzfeld, M. Practical Mediterraneanism: Excuses for Everything, from Epistemology to Eating. In Rethinking the Mediterranean; William, V., Ed.; Oxford University Press: Oxford, UK, 2005; pp. 45-63.

3. Boriçi, G. Marrëdhëniet Shqiptaro-Kineze Në Luftën e Ftohtë; Mirgeeralb: Tirana, Albania, 2016; pp. 93-105, 110-120.

4. Mëhilli, E. States of Insecurity. Int. Hist. Rev. 2015, 37, 1037-1058. [CrossRef]

5. Mëhilli, E. Enver Hoxha's Albania: Yugoslav, Soviet, and Chinese relations and ruptures. In The Routledge Manual of Balkan and Southeast European History; John, R., Ed.; Routledge: London, UK, 2021; pp. 447-455.

6. Hoxha, A.R. Tharja e Kënetës së Maliqit dhe Ndërtimi i Regjimit Komunist në Periferi të Shqipërisë; Onufri: Tirana, Albania, 2021; pp. 215-239.

7. Hoxha, A.R. Sugarland: Socialism and the Transformation of the Albanian Countryside. Ph.D. Thesis, University of Pittsburgh, Pittsburgh, PA, USA, 2020; pp. 140-147.

8. Mëhilli, E. From Stalin to Mao: Albania and the Socialist World; Cornell University Press: New York, NY, USA, 2017 ; pp. 54-129.

9. Biberaj, E. Albania-Chinese Relations 1962-1969. Tirana Observatory, 6 July 2020.

10. Albanian Central Archive, Collection of the Albanian Labor Party's Central Committee, year 1961, file 47, sheet 41.

11. Mëhilli, E. Globalized Socialism, Nationalized Time: Soviet Films, Albanian Subjects, and Chinese Audiences Across the Sino-Soviet Split. Slav. Rev. 2018, 77, 611-637. [CrossRef]

12. Holquist, P. State Violence as Technique: The Logic of Violence in Soviet Totalitarianism. In Landscaping the Human Garden: Twentieth-Century Population Management in a Comparative Framework; Weiner, A., Ed.; Stanford University Press: Stanford, CA, USA, 2003; pp. 19-45.

13. Woodcock, S. Life is War: Surviving Dictatorship in Communist Albania; Hammer on Press: Bristol, UK, 2016.

14. Arapi, O.; Repishti, A.; Toporja, A.; Dosari, E. (Eds.) Të Mohuar Nga Regjimi: Burgjet, Sistemi i Internim-Dëbimeve Dhe Puna e Detyruar Në Shqipëri Në 1945-1990; KAS: Tirana, Albania, 2020.

15. Naimark, N. Stalin and the Fate of Europe: The Postwar Struggle for Sovereignty; The Belknap Press of Harvard University Press: Cambridge, MA, USA; London, UK, 2019; pp. 54-87.

16. Shqipëria në Dokumentet e Arkivave Ruse; Collection of Soviet documents on Albania edited and translated from Russian to Albanian from Islam Lauka \& Eshref Ymeri; Toena: Tirana, Albania, 2006; pp. 201-221.

17. Fitzpatrick, S. Becoming Cultured: Socialist Realism and the Representation of Privilege and Taste in Sheila Fitzpatrick. In The Cultural Front: Power and Culture in Revolutionary Russia; Cornell University Press: London, UK, 1992; pp. $216-237$.

18. Hessler, J. Cultured Trade: The Stalinist Turn Toward Consumerism. In Stalinism: New Directions; Fitzpatrick, S., Ed.; Routledge: London, UK, 2000; pp. 182-209.

19. Ilič, M. What Did Women Want? Khrushchev and the Revival of the Zhensovety. In Soviet State and Society under Nikita Khrushchev; Ilič, M., Smith, J., Eds.; Routledge: London, UK, 2009; pp. 104-121.

20. Ilič, M. Women in the Khrushchev Era: An Overview. In Women in the Khrushchev Era; Ilič, M., Reid, S.E., Attwood, L., Eds.; Palgrave Macmillan: New York, NY, USA, 2004; pp. 5-28.

21. Central State Archive, Collection of the Albanian Labor Party's Central Committee, Year 1954, file 16, sheet 28-29.

22. Lalaj, A. Desperate Divorces (An Overview of the Marriages between Albanian and Foreign Citizens). Law Chance Dev. Women 1 2008, 18, 56-58. 
23. Central State Archive, Collection of the Prime Ministry Office, Year 1954, file 140, sheet 1-7.

24. Central State Archive, Collection of the Albanian Labor Party's Central Committee, Year 1959, file 11, sheet 180-183.

25. Central State Archive, Collection of the Albanian Labor Party's Central Committee, Year 1959, file 32, sheet 214.

26. Koçiko, A. Ushtarakë shqiptarë dhe grate ruse, gëzimi dhe mallkimi i një epoke. Dita, 13 May 2016.

27. Koçiko, A. Letra sekrete: Historitë e ushtarakëve shqiptarë dhe grave ruse. Dita, 5 April 2018.

28. Volkov, V. The Concept of kul'turnost': Notes on the Stalinist Civilizing Process. In Stalinism: New Directions; Fitzpatrick, S., Ed.; Routledge: London, UK, 2000; pp. 210-230.

29. Kudrickaya, T. Dashuritë shqiptaro-ruse në dy sisteme. Panorama, 13 June 2018.

30. Pisha, T. Shpresuam Dhe Mbijetuam; Translated from Russian to Albanian Sokrat Gjerasi; Omsca-1: Tirana, Albania, 2016 ; p. 19.

31. The Archive of the Ministry of Interior, Branch 2, Year 1965, file 49, sheet 11-20.

32. Lalaj, A. Pranvera e rrejshme e '56- ës; Infobotues: Tirana, Albania, 2015.

33. Trotsky, L. The Revolution Betrayed: What Is the Soviet Union and Where Is It Going? Eastman, E., Ed.; Pathfinder Press: New York, NY, USA, 1972.

34. Timasheff, N. The Great Retreat: The Growth and Decline of Communism in Russia; E.P. Dutton \& Co: New York, NY, USA, 1946.

35. Djilas, M. The New Class: An Analysis of the Communist System; Thames \& Hudson: London, UK, 1957.

36. Fitzpatrick, S. Cultural Revolution as Class War. Cultural Revolution in Russia, 1928-1931; Fitzpatrick, S., Ed.; Indiana University Press: Bloomington, IN, USA, 1978; pp. 8-40.

37. Central State Archive, Collection of the Albanian Labor Party's Central Committee, year 1959, file 484, sheet 1-4.

38. Central State Archive, Collection of the Albanian Labor Party's Central Committee, year 1963, file 4, sheet 267 \& 278.

39. Lalaj, A. Ndarje të trishtuara: Një vështrim historik-juridik mbi martesat midis shtetasve shqiptarë dhe të huaj. Stud. Hist. 2010, 2, 368 .

40. Biberaj, E. Albania. In Eastern Europe: Politics, Culture, and Society since 1939; Ramet, S.P., Ed.; Indiana University Press: Bloomington, IN, USA, 1998; p. 257.

41. Pano, N.C. Albania. In Communism in Eastern Europe; Rakowska-Harmstone, T., Gyorgy, A., Eds.; Indiana University Press: Bloomington, IN, USA; London, UK, 1979; p. 196.

42. Smirnova, N. Historia e Shqipërisë Përgjatë Shekullit XX; Translated from Russian to Albanian Korab Hoxha \& Fatmir Mborja; Ideart: Tirana, Albania, 2004; pp. 380-406.

43. Prifti, P. Albania and the Sino-Soviet Conflict. In Remote Albania: The Politics of Isolation; Onufri: Tirana, Albania, $1999 ;$ pp. 65-70.

44. Rothschild, J. Return to Diversity: A Political History of East Central Europe Since World War II, 2nd ed.; Oxford University Press: New York, USA, 1993; pp. 175-176.

45. Prifti, P. The Labor Party of Albania. In Remote Albania: The Politics of Isolation; Prifti, P., Ed.; Onufri: Tirana, Albania, 1999; pp. 178-180.

46. Biberaj, E. Albania in Transition: The Rocky Road to Democracy; Westview Press: Boulder, CO, USA, 1998 ; p. 25.

47. Isaku, V. Libër i Hapur: Ruset Në Shqipëri; Omsca-1: Tirana, Albania, 2008.

48. Kaloçi, D. Dhelprat/Si i zbuloi Sigurimi gratë ruse në Tiranë e Shkodër me ndihmën e 'Vullnetit' dhe 'Mimozës'. Mapo, 12 November 2018.

49. Kaloçi, D. Dokumenti: Si u zbulua dhe u godit grupi “Dhelpra” i grave ruse në Tiranë dhe Shkodër me ndihmën e bashkëpunëtorëve 'Vullneti,' 'Mimoza,' dhe 'Frekuenca,' (dhe fotot e panjohura). Tema, 12-13 November 2018.

50. Browning, C.; Siegelbaum, L. Frameworks for Social Engineering: Stalinist Schema of Identification and the Nazi Volksgemeinschaft. In Beyond Totalitarianism: Stalinism and Nazism Compared; Fitzpatrick, S., Geyer, M., Eds.; Cambridge University Press: Cambridge, UK, 2009; pp. 231-265.

51. Hoffmann, D.L. European Modernity and Soviet Socialism. In Russian Modernity: Politics, Knowledge, Practices; Hoffmann, D.L., Kotsonis, Y., Eds.; Palgrave Macmillan: London, UK; New York, NY, USA, 2000.

52. Fitzpatrick, S. Ascribing Class: The Construction of Social Identity in Soviet Russia. J. Mod. Hist. 1993, 65, 745-770. [CrossRef]

53. Weitz, E.D. Racial Politics without the Concept of Race: Reevaluating Soviet Ethnic and National Purges. Slav. Rev. 2002, 21, 1-29. [CrossRef]

54. Fritzsche, P.; Hellbeck, J. On Stalin's use of harsh punishments of the alleged enemies as a preventive measure. The New Man in Stalinist Russia and Nazi Germany. In Beyond Totalitarianism: Stalinism and Nazism Compared; Fitzpatrick, S., Geyer, M., Eds.; Cambridge University Press: Cambridge, UK, 2009; p. 340.

55. Weiner, A. Nature, Nurture, and Memory in a Socialist Utopia: Delineating the Soviet Socio-Ethnic Body in the Age of Socialism. Am. Hist. Rev. 1999, 194, 1114-1155. [CrossRef] 